\title{
The role of underground gas storage facilities in the continuous supply of natural gas to domestic recipients based on the example of the Visegrad Group
}

ABSTRACT: Underground gas storage facilities play an important part in the maintenance of balance between the constantly imported raw material and variable gas demand in the discussed part of Europe. They also allow for more the efficient operation of businesses which exploit this raw material in this part of Europe and operators of power lines.

The following issues will be discussed in the article: types, capacity, location and variability of the filling level of underground gas storage facilities in Poland, the Czech Republic, Hungary, and Slovakia; similarities and differences in the policy of natural gas storage between individual Visegrad Group countries; the influence of these differences on the situation in the gas market; the influence of the planned further reconstruction of the natural gas storage facilities system on the energy security of individual countries which belong to the Visegrad Group.

Concern for UGSF is one of the conditions of expansion of transmission pipelines to the north and south, increase of LNG import within the Visegrad Group, or the creation of a gas hub in Poland initiatives aimed at, among others, securing the continuity of supplies to domestic users.

However, the current and planned investments indirectly indicate that in the policies of the governments of the Visegrad Group countries, UGSF are supposed to soon play a much smaller role than

Corresponding Author: Tomasz Skrzyński; e-mail: tomasz.skrzynski@up.krakow.pl

1 Institute of Safety Studies, Pedagogical University of Krakow, Poland; ORCID iD: 0000-0003-2063-4396; e-mail: tomasz.skrzynski@up.krakow.pl

2020. The Author(s). This is an open-access article distributed under the terms of the Creative Commons Attribution-ShareAlike International License (CC BY-SA 4.0, http://creativecommons.org/licenses/by-sa/4.0/), which permits use, distribution, and reproduction in any medium, provided that the Article is properly cited. 
many researchers would expect. An intensive expansion of UGSF is very unlikely.

The scale of the state's effect on the role of storage facilities in supplying gas to users depends on the level of the state's control over the companies managing UGSF.

KEYWORDS: energy policy, underground gas storage facilities, natural gas market, gas infrastructure

\section{Introduction}

In the scope of energy security, the EU Member States have the possibility to individually develop their energy security (Gryz et al. eds. 2018).

The analysis focuses on the V4 countries due to, among others, their similar geographical location; the scale of gas pipeline connections between the analyzed countries; similar challenges faced by the energy policies of these 4 countries. The said challenges include e.g. an infrastructure in need of modernization and expansion, oriented at imports from the East, and a structure of gas imports (e.g. Trubalska 2017; MOL 2019).

At the same time, according to Gazprom data from 2018, these 4 countries are the largest importers of gas from Russia in the entire area of Central Europe and the Balkan Peninsula (not including Turkey). According to Gazprom data, at the time Poland made up 4.91\% of Gazprom deliveries in Europe. It constituted 109.45 TWh. Hungary was second, with a slightly lower figures: $3.69 \%$ and $82.25 \mathrm{TWh}$, respectively. In the case of Czechia, it was $3.23 \%$ and $72.04 \mathrm{TWh}$, respectively. For Slovakia, the figures were $2.53 \%$ and 56.39 TWh. If each of these countries were analyzed separately, then only Poland would be counted among the 10 major European importers of gas from Russia. The situation changes completely when the Visegrad Group countries are treated jointly as a whole. This would put the V4 countries in second place (behind Germany) in terms of the volume of the imports of gas from Russia (gazpromexport.ru).

An important element in ensuring energy security of the supply of raw materials to recipients in countries being large-scale importers of gas is, both in a short- and in a long-term perspective, care for the appropriate condition and capacity of underground gas storage facilities.

The main objectives of the article are: to describe the role of UGSF (Underground Gas Storage Facilities) in ensuring the continuity of supply in the policies of Visegrad Group countries; to demonstrate how state authorities perceive these roles in practice. For the purpose of these objectives, the presentation of the kinds, capacities, and distribution of underground gas storage facilities in Poland, Czechia, Hungary, and Slovakia is justified.

The following questions were addressed:

$\checkmark$ What is the current actual role of UGSF in ensuring the continuity of supply of natural gas to domestic recipients in the Visegrad Group?

$\checkmark$ What are the similarities and differences in the scope of the policies of storage of natural gas between the Visegrad Group countries? 
$\checkmark$ To what extent does the cooperation between the Visegrad Group countries, as described by some researchers, currently pertain to UGSF?

The following hypotheses were examined:

$\checkmark$ The diversification between the Visegrad Group countries in terms of storing natural gas is significantly higher than most researchers agree.

- There is a discrepancy between official declarations made by the authorities of individual countries regarding the role of UGSF in ensuring energy security and political practices.

\ There is currently a disparity between the significance of UGSF for ensuring the continuity of supply of natural gas to domestic recipients and the actual policies of the authorities of individual countries in the scope of storage of natural gas.

After 2015, few publications encompassing the majority of issues of the topic in question have been issued (e.g. Kutyła 2016). In some texts, they remain on the margin of the general description of gas markets in the discussed countries (Dyduch and Skorek 2020; Kłaczyński 2018; Osička et al. 2018; Ruszel and Szurlej 2016). The core of the source literature is of a narrower scope. For instance, it sometimes includes only one of the four countries (e.g. Ciechanowska 2016). Also the plans of government authorities until 2015 and forecasts concerning the gas market have been analyzed (e.g. Olkuski et al. 2017; Ruszel 2017; Olkuski et al. 2015). The EU energy policy has been competently described as well (Tomaszewski 2018).

This article will be mostly based on data from 2019. In terms of data, this draft is based on, among others, BP Statistical, Gas Infrastructure Europe, Eurostat, EGA, "The Energy Policy of Poland by 2040" project and Report of the President of the Energy Regulatory Office in 2019. A part of important data regarding the issue in question for the year 2019 is not available to researchers yet (e.g. Eurostat, EIG 2018).

This article applies the following research methods: the rational approach to the issue of energy policy; factor analysis; and elements of comparative analysis.

\section{Capacity, distribution, plans for expanding UGSF}

In the discussed countries, a vast majority of gas is stored in depleted gas/oil fields. In Hungary and Slovakia, they make up 100\% of the storage facilities. Poland and Czechia also use salt caverns for this end. Most of them constitute UGSF based on depleted gas fields. One example of a storage facility created based on depleted oil fields is Dambořice in Czechia. UGSF in aquifers and in drilled rocks are found only in Czechia (in the region of Lobodice and Háje) (GIE 2020a). The level of diversification of UGSF in the discussed area only in part results from geological conditions. The advantages of UGSF located in exhausted gas deposits include: relatively low construction costs, low risk of gas leakage (cf. Schultz et al. 2020), and a 1:1 ratio of cushion gas (which must at all times be present in the storage facility) to work gas. The biggest flaw is 
the long time necessary to fill and to extract the raw material. Cavity storage facilities are more costly in construction, but they are more efficient (Więckowski 2015) and safer from the point of view of protecting the storage facilities from terrorist attacks and limiting the gas exhalation from UGSF, because they are made up of a number of separate chambers (e.g. Mrzygłód 2018).

The discussed countries differ in the capacity of storage facilities in relation to gas consumption. The largest volumes are found in Hungary and Slovakia. They offer lower capabilities for supply diversification (Stopa and Kosowski 2018).

The other countries use coal to produce energy on a large scale and have direct access to Germany, which has diversified sources of gas supply and the EU's largest UGSF capacity. Czechia has the most diversified gas supply network (Kłaczyński 2017a). Poland is the only country which can import LNG by sea. At the same time, however, it is the only one to not have nuclear power in its energy mix. Meanwhile, the other countries not only have nuclear power plants, but nuclear energy also plays an important role in their energy mixes. Slovakia has by far the largest share of nuclear energy (BP Statistical 2020; Eurostat 2019).

In terms of natural gas consumption in the world, in 2018 Poland ranked 37 (219 TWh), Hungary 46 (107 TWh), Czechia 49 (89 TWh). The least amount of natural gas is consumed in Slovakia (Wang 2019; BP Statistical 2020). This data did not change significantly in 2019 (see: Table 1).

TABLE 1. Gas consumption in the Visegrad Group (2008-2019) [TWh]

TABELA 1. Zużycie gazu w Grupie Wyszehradzkiej (2008-2019) [TWh]

\begin{tabular}{|l|r|r|r|r|r|r|r|r|r|r|r|r|}
\hline \multicolumn{1}{|c|}{ State } & 2008 & 2009 & 2010 & 2011 & 2012 & 2013 & 2014 & 2015 & 2016 & 2017 & 2018 & 2019 \\
\hline $\begin{array}{l}\text { Czech } \\
\text { Republic }\end{array}$ & 92.13 & 87.69 & 104.34 & 87.69 & 88.8 & 89.91 & 79.92 & 83.25 & 91.02 & 93.24 & 88.8 & 92.13 \\
\hline Hungary & 136.53 & 117.66 & 126.54 & 120.99 & 107.67 & 101.01 & 89.91 & 96.57 & 103.23 & 109.89 & 106.56 & 108.78 \\
\hline Poland & 173.16 & 167.61 & 179.82 & 183.15 & 193.14 & 193.14 & 188.70 & 189.81 & 203.13 & 213.12 & 220.89 & 226.44 \\
\hline Slovakia & 31.75 & 28.30 & 30.64 & 33.08 & 31.75 & 31.08 & 26.97 & 27.53 & 26.64 & 27.31 & 27.86 & 49.95 \\
\hline
\end{tabular}

Source: BP Statistical 2019, 2020; SLOVSTAT 2020, Eurostat 2020.

When comparing data for the last 10 years, the tendencies in the use of gas in the economies of individual Visegrad Group countries differ. Only in Poland has there been a clear and systematic increase of the consumption of natural gas, both in general terms as well as per the number of inhabitants. According to the available data, the other 3 countries had a lower consumption of gas in 2018 and 2019 than in 2010 (Table 1). However, it needs to be noted that the consumption of gas in Poland per inhabitant in 2019 was still lower than in Czechia, Hungary and Slovakia (Table 2).

The share of natural gas production in the total energy production in 2017 also differed. It was as follows: Hungary 12.7\%; Poland 5.5\%; and Slovakia 1.8\%. It was very low in Czechia (Eurostat 2019). 
TABLE 2. Consumption of natural gas in the Visegrad Group countries per inhabitant in the period 2008-2019 [MWh]

TABELA 2. Zużycie gazu w państwach Grupy Wyszehradzkiej w przeliczeniu na jednego mieszkańca w latach 2008-2019 [MWh]

\begin{tabular}{|l|r|r|r|r|r|r|r|r|r|r|r|r|}
\hline & 2008 & 2009 & 2010 & 2011 & 2012 & 2013 & 2014 & 2015 & 2016 & 2017 & 2018 & 2019 \\
\hline $\begin{array}{l}\text { Czech } \\
\text { Republic }\end{array}$ & 8.88 & 8.44 & 9.99 & 8.32 & 8.44 & 8.55 & 7.55 & 7.88 & 8.66 & 8.77 & 8.44 & 8.66 \\
\hline Hungary & 13,542 & 11,766 & 12,654 & 12,099 & 10,878 & 10,212 & 9,102 & 9,768 & 10,545 & 11,211 & 10,878 & 11,100 \\
\hline Poland & 4,551 & 4,440 & 4,773 & 4,440 & 5,106 & 5,106 & 4,962 & 5,006 & 5,328 & 5,661 & 5,883 & 5,994 \\
\hline Slovakia & 5,883 & 5,217 & 5,661 & 6,105 & 5,883 & 5,772 & 4,995 & 5,106 & 4,884 & 4,995 & 5,106 & 9,102 \\
\hline
\end{tabular}

Source: BP Statistical 2019, 2020; SLOVSTAT 2020, Eurostat 2020.

On a multi-annual scale, the production of gas in the discussed countries shows a decreasing trend. However, the situation is different in individual countries in the period 2015-2019, both in absolute numbers and in comparison to the needs of the economy. As transpires from the data in Table 1, an increase in gas consumption in Poland has been visible since 2015 (from 189,81 to $226,44 \mathrm{TWh}$ ), along with slow a decrease of its production (from 47,73 to 44,4 TWh). The trend partially changed in 2019. In 2018, production dropped by $1.5 \%$ and in 2019 it rose by $0.1 \%$. However, a comparison with the consumption growth is not favorable. In Poland in 2019, consumption rose by $2.3 \%$ and the production rose by $0.1 \%$ in relation to 2018 (BP Statistical 2020).

In Hungary in the period 2009-2019, production fell from 29,557 TWh to 17,004 TWh. A smaller drop on a 10-year scale was recorded in Czechia (IEA 2019). Despite searches for the raw material, gas production in Slovakia has been at a very low level for many years (Michalik 2019) from 0.99 to 1.64 TWh (IEA 2019).

In 2017 , the energy dependency rate was $105.6 \%$ for Slovakia, $101.9 \%$ for Czechia, $96.3 \%$ for Hungary, and $77.8 \%$ for Poland. At that time, only Poland had a rate similar to the EU average of $74.3 \%$ (Eurostat 2019).

Also prices of gas for households varied. In the second half of 2018, they were the lowest in Hungary, and the highest in Czechia (Eurostat 2019). As can be seen in Figure 1, in 2018, in terms of UGSF capacity, Hungary ranked 8 in Europe (67.51 TWh); Poland 10 (46.51 TWh); Czechia 12 (42.58 TWh); and Slovakia 13 (39.19 TWh).

The gas consumption parameters of UGSF in individual countries also vary (Table 3 ). In 2018, gas consumption in Poland was 0.184 TWh; 0.105 TWh in Hungary; 0.087 TWh in Czechia; and 0.051 TWh in Slovakia (Fig. 1).

The presented maximum value of deliverability (Table 3 ) is not always attainable. In the case of the UGSF kind that is dominant in the V4 countries, sometimes the injected gas is mixed with the cushion gas. One example is Poland's largest UGSF - Wierzchowice. As a result, the received gas is sometimes of a lesser quality than the injected gas (Stopa et al. 2019).

The distribution of storage facilities on the V4 scale varies greatly. As is demonstrated in Figure 2, in Poland and Hungary, they are quite evenly distributed around the country. It needs 


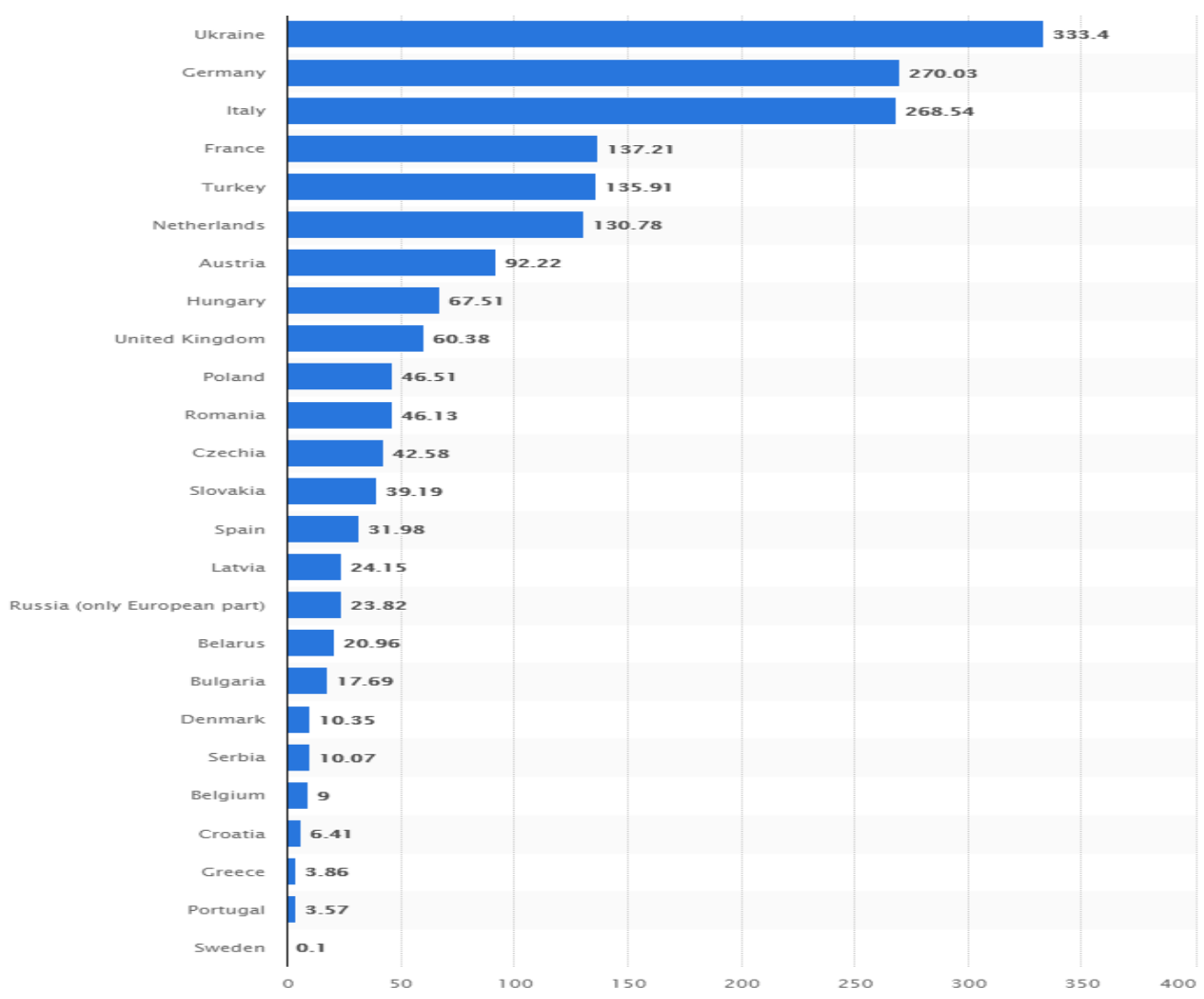

Fig. 1. Technical working gas volume in underground storage facilities in Europe by country in 2018 Source: Sönnichsen 2020

Rys. 1. Objętość robocza gazu w podziemnych magazynach w Europie według kraju 2018

TABLE 3. UGSF collective data for the period from 1 April 2018 to 31 March 2019 [TWh/day]

TABela 3. PMG dane zbiorcze za okres 1 kwietnia 2018 - 31 marca 2019 r. [TWh dziennie]

\begin{tabular}{|l|c|c|c|c|}
\hline \multicolumn{1}{|c|}{ State } & Czech Republic & Hungary & Poland & Slovakia \\
\hline Deliverability & 0.703 & 0.836 & 0.575 & 0.465 \\
\hline Injection & 0.494 & 0.473 & 0.326 & 0.411 \\
\hline Maximum production & 0.005 & 0.055 & 0.089 & - \\
\hline
\end{tabular}

Source: GIE 2020b.

to be remembered, however, that individual UGSF differ significantly in terms of deliverability. A very uneven distribution of UGSF can be found in Czechia (almost only in the east of the country; a large part of storage facilities are located close to borders) and, in particular, Slovakia. 
At the same time, all Slovak gas storage facilities are located in the same region. It is the highest concentration of available UGSF capacity in a country in one place compared to other Visegrad Group countries. Such concentration of storage facilities in one region is in this case conducive to supplying gas to the market (distribution of industrial infrastructure) and safe in case of terrorist attacks. Obviously, such distribution is also connected with geological conditions. It is no coincidence that the only UGSF in central Czechia is located in a system of tunnels carved out in rock.

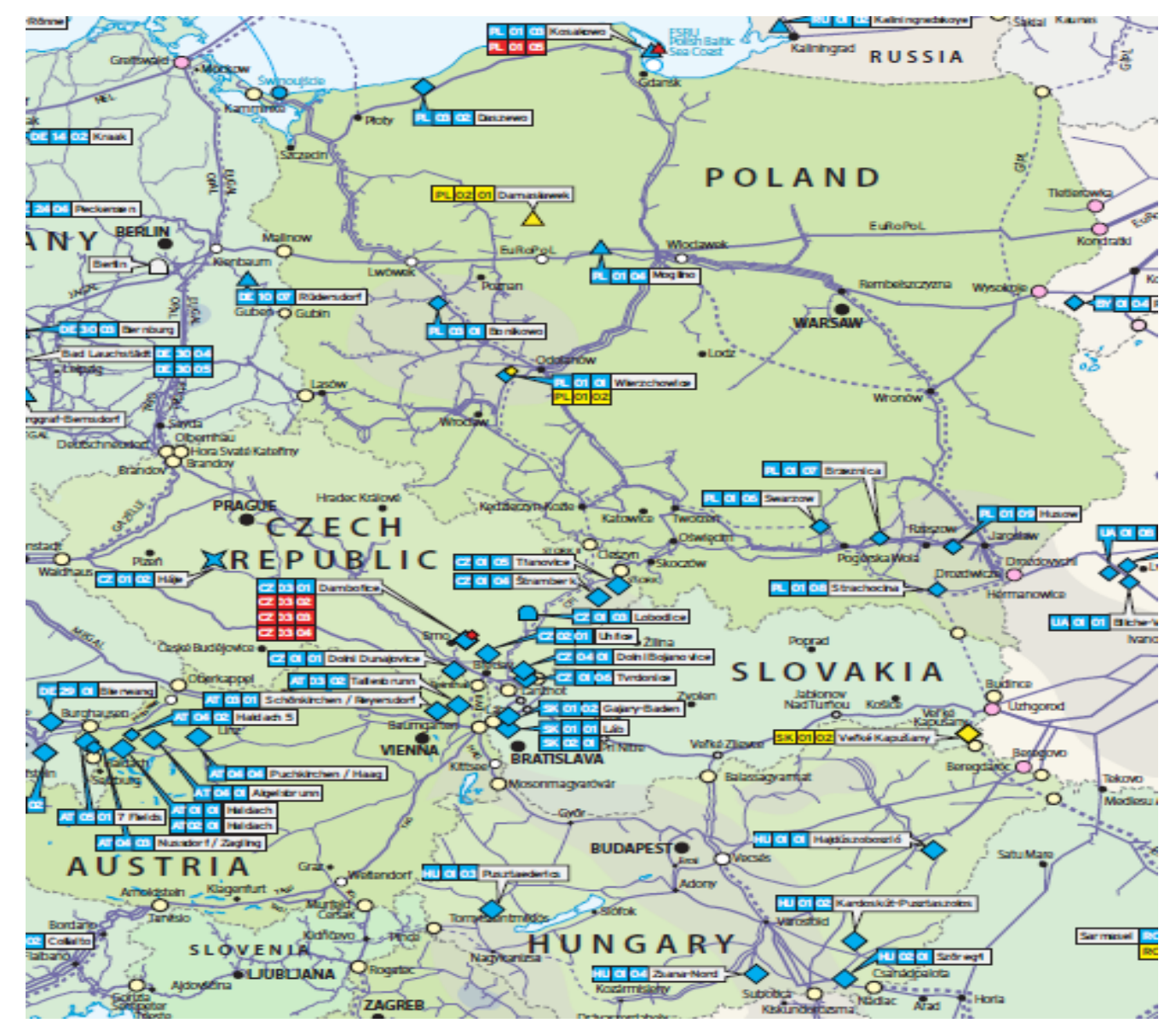

Fig. 2. UGSF of Poland, Hungary, Czech Republic and Slovakia

Source: GIE Storage Map 2018

Rys. 2. PMG w Polsce, na Węgrzech, w Czechach i na Słowacji 


\section{The role of underground gas storage facilities in the continuous supply - from plans to reality}

Ciechanowska estimated that, in order to ensure security of supplies for end users, the active capacity of UGSF should reach at least $30 \%$ of annual demand (Ciechanowska 2016). The store capacities necessary for this purpose were modest due to an approach based on harmonious cooperation with Russia and other intermediaries and recipients of gas, and a failure to implement plans to build connections alternative to those running through Visegrad Group countries. When these hopes were proven false; extension works on storage facilities began (see: Table 4).

TABLE 4. Working capacity of UGSF of Poland, Hungary, Czechia and Slovakia in 2011-2020 [expressed in TWh]

TABELA 4. Robocza pojemność gazu w PMG Polski, Węgier, Czech i Słowacji w latach 2011-2020 [w przeliczeniu na TWh]

\begin{tabular}{|c|c|c|c|c|}
\hline Day & Poland & Hungary & Czechia & Slovakia \\
\hline 01.01 .2011 & 7.75 & 67.13 & 25.14 & 29.80 \\
\hline 01.01 .2012 & 17.74 & 67.13 & 26.74 & 30.61 \\
\hline 01.01 .2013 & 20.10 & 67.13 & 28.38 & 31.14 \\
\hline 01.01 .2014 & 20.10 & 67.13 & 28.60 & 32.02 \\
\hline 01.01 .2015 & 28.04 & 67.13 & 34.60 & 37.09 \\
\hline 01.01 .2016 & 31.08 & 67.13 & 34.60 & 33.93 \\
\hline 01.01 .2017 & 32.57 & 67.13 & 34.83 & 35.95 \\
\hline 01.01 .2018 & 33.20 & 67.43 & 34.83 & 38.03 \\
\hline 01.01 .2019 & 33.20 & 67.53 & 34.83 & 39.85 \\
\hline 01.01 .2020 & 34.20 & 69.64 & 36.24 & 42.54 \\
\hline
\end{tabular}

Source: GIE 2020d; GIE 2020e; GIE 2020f.

The weakening of the said countries' role of intermediaries in gas supply increases the importance of gas storage facilities as a vital element in providing stable supplies in the V4 countries. According to the findings of Michal Mejstř́k from 2011, initially Poland intended to store 54.4 TWh of gas in 15 UGSF; Slovakia 54.4 TWh in 6 UGSF; Hungary 51.06 TWh in 6 UGSF (Mejstř́k 2011).

These plans have been changing over the years. Poland may serve as an example. In 2009, there were 6 facilities allowing for the storage of 18.315 TWh of gas. Between 2013 and 2018, plans were made to expand the storage capacity by $14.43 \mathrm{TWh}$. An increase by $1.1 \mathrm{TWh}$ between 
2014 and 2023 was also planned (Executive works program 2015-2018). In 2015, the "Gas Review" ("Przegląd Gazowniczy") magazine highlighted that the optimal solution would be to double the then capacity of UGSF in Poland from 28.86 to 55.5 TWh of gas (Hadam 2015). In 2017, it was estimated that by 2020 Polish UGSF would be expanded to approximately 44.4 TWh (Ruszel 2017).

Finally, in the years 2009-2018, the capacity of UGSF was increased from $12 \%$ to $17 \%$ of annual gas consumption. Six storage facilities, including two cavity ones, were constructed or expanded (PEP 2040). In 2019, this percentage value probably decreased. At the end of 2019, the authorities officially planned the further expansion of UGSF to the level of 44.4 TWh until the 2030/2031 winter season and to increase the current maximum gas output capacity from storage installations - from 0.54 TWh do 0.67 TWh/day (PEP 2040). The Polish authorities planned to carry out an extensive extension of UGSF in autumn 2020 (Poland's Energy Policy 2040 summary). Simultaneously, a new cavity storage facility is being planned in Poland. The pace of work, however, is not high. It is no coincidence that the planned expansion of the Kosakowo storage facility by $0.55 \mathrm{TWh}$ was moved from September 2021 to 2022 (e.g. PGNiG 2020). This has possibly been due to geological or technical reasons, and the high costs due to which the proposals to build Polish UGSF in aquifers remain unimplemented. For comparison, in April 2020, gas storage facilities on the EU level allowed storing over 1,200 TWh.

Of course, plans to expand the UGSF capacity are developed also in other V4 countries. For instance, most companies which deal with the storage of gas in Czechia have such plans (e.g. MND 2019).

When assessing this data, it is worth adding that there is a possibility to increase gas pressure by $20 \%$ in storage facilities constructed in exhausted gas deposits. However, exceeding this increased threshold poses a risk of unsealing of deposit rocks (Filar 2018).

At the end of 2019, the stability of gas supply to countries cooperating within the Visegrad Group is mainly threatened by:

$\downarrow$ possibility to use gas pipelines for energy blackmail;

$\checkmark$ Russia's exploitation of intra-EU differences;

$\downarrow$ disproportion between funds allocated for the activity of geological surveys in Russia and the scale and complexity of tasks they face in terms of gas;

$\downarrow$ Russia's influence on the levels of exports of gas from Turkmenistan, Azerbaijan, and Kazakhstan;

$\checkmark$ significant decrease of funds allocated by Russia for the modernisation and expansion of the infrastructure used for the supply of the raw material to the West, as well as search and production of gas from new deposits (Skrzyński 2019; Milovidov 2017);

$\downarrow$ in Russia in 2015-2019, the number of overhauls of gas pipelines conducted by Gazprom per kilometer halved (GAZPROM 2020).

The government policies in Poland and in Hungary are facilitated thanks to the full control over UGSF being exercised by state-controlled energy enterprises - Gas Storage Poland and a company being a part of MOL group. The domination of the storage sector by a single enterprise ordering a storage reserve results from the attitude of the governments of these countries 
towards becoming dependent upon the supply of this raw material from the East (Brzeziński and Wawrzynowicz 2014). Poland and Hungary have 7 and 5, respectively, storage facilities for methane-rich natural gas.

The governments of the other countries have less room for maneuver. In 2019, there were 9 active UGSF in Czechia. At the same time, the policy of the Czech authorities in the scope of gas storage is hindered due to the variation of entities which manage UGSF being much higher than in other Visegrad Group countries. The state's control over the UGSF is also much lower than in Poland, Hungary or Slovakia. In 2020, the largest UGSF operator was innogy Gas Storage, s.r.o., which is part of innogy SE. According to this company, the capacity of its 6 storage facilities equals about two-month gas consumption in Czechia in the heating season (innogy Gas Storage). As of June 15 2020, the rate of injection and extraction of gas in those UGSF was in total $0.267 \mathrm{TWh}$ and $0.343 \mathrm{TWh}$, respectively (innogy Gas Storage 2020).

From among the other companies which manage UGSF in Czechia (see: Table 5), Moravia Gas Storage needs mentioning. This company, in which Gazprom holds a significant amount of shares, is definitely expanding its storage capacities the most (e.g. Gazprom 2020). For Gazprom, they constitute e.g. security of supplies to the EU in the event of yet another conflict between Russia and Ukraine.

TABLE 5. The capacity and efficiency of UGSF of the Visegrad Group countries as of July 1, 2018

TABeLa 5. Pojemność i wydajność PMG Grupy Wyszehradzkiej na dzień 1 lipca 2018 r.

\begin{tabular}{|l|c|c|c|c|}
\hline \multicolumn{1}{|c|}{ Country } & Operator & $\begin{array}{c}\text { Working gas } \\
\text { (technical }) \\
{[\mathrm{TWh}]}\end{array}$ & $\begin{array}{c}\text { Withdrawal } \\
\text { technical } \\
{[\mathrm{TWh} / \text { day }]}\end{array}$ & $\begin{array}{c}\text { Injection technical } \\
{[\mathrm{TWh} / \text { day }]}\end{array}$ \\
\hline Czech Republic & innology Gas Storage & 28.71 & 0.42229 & 0.31550 \\
\hline Czech Republic & MND Gas Storage & 3.08 & 0.10721 & 0.05767 \\
\hline Czech Republic & Moravia Gas Storage & 4.68 & 0.07820 & 0.04692 \\
\hline Czech Republic & SPP Storage & 6.12 & 0.09558 & 0.07434 \\
\hline Hungary & Hungarian Gas Storage & 47.40 & 0.61764 & 0.39874 \\
\hline Hungary & $\begin{array}{c}\text { MMBF [Hungarian } \\
\text { Hydrocarbon Stockpiling } \\
\text { Association] }\end{array}$ & 20.11 & 0.26390 & 0.13406 \\
\hline Poland & Gas Storage Poland & $34.20^{*}$ & 0.54296 & 0.30470 \\
\hline Slovakia & Nafta & 28.64 & 0.40671 & 0.34190 \\
\hline Slovakia & Pozagas & 6.95 & 0.07266 & $0.07266(?)$ \\
\hline $\begin{array}{l}\text { Visegrad Group } \\
\text { countries }\end{array}$ & $\begin{array}{c}\text { 9 enterprises (dealing } \\
\text { with the storage of gas) }\end{array}$ & 179.89 & 2.608 & 1.747 \\
\hline
\end{tabular}

* As of $31^{\text {st }}$ December 2019.

Source: GIE 2018; URE 2019. 
This success of Russia's energy policy, aimed at taking over energy sectors in the V4 countries, contrasts with the attitude of the Hungarian government. At a cost of various concessions, they managed to reclaim the shares of MOL enterprise from Gazprom (Kłaczyński 2017a).

One facility more effective than the total capacity of UGSF managed by innogy Gas Storage is the gas storage facility of key importance for the energy security of Slovakia. Its maximum injection capacity is $0.338 \mathrm{TWh}$, and the maximum extraction capacity is $0.392 \mathrm{TWh}$ (NAFTA 2020). It is located in the region of Láb, close to the country's most important connection of the transit and capital gas pipelines.

In Slovakia, the storage of gas is handled mainly by the NAFTA a.s. enterprise. It also runs storage activity in Czechia, among others. It is controlled by SPP Infrastructure, $51 \%$ of its shares are controlled by the Republic of Slovakia. The significant shareholding by foreign capital (EPH and EPIF 2016; NAFTA 2018) is not surprising, considering the lower financial capacity of Slovakia (compared e.g. with Poland).

As of January 1, 2020, there were a total of 23 methane-rich natural gas storage facilities operating in these countries, with a joint capacity of $182.62 \mathrm{TWh}$ (Table 4). The demand for natural gas in the V4 countries in 2019 was 478.41 TWh. Based on that, it can be assumed that, with the storage facilities being filled to $100 \%$, the UGSF in the said countries at the beginning of January 2020 could cover up to $38.17 \%$ of the annual demand. It needs to be remembered, however, how large the differences in this respect between the different countries are. On August 12, 2020, the storage facilities of the Visegrad Group countries were almost completely full (Czechia 91.6\%; Slovakia 89.5\%; Poland 89.4\%; Hungary 88.3\%). According to Ukrainian sources, their maximum working capacity at the time was as follows: $37.84 \mathrm{TWh}$; $45.15 \mathrm{TWh}$; 37.73 TWh and 73.89 TWh of natural gas, respectively (Naftogaz 2020). Importantly, works are being carried out aimed at opening more storage facilities (e.g. Vel'ké Kapušany in Slovakia or Damasławek in Poland).

In the case of tense international relationships and an economic war, UGSF allow for creating and maintaining strategic gas reserves. In 2019, such a role of gas storage facilities was fostered by the threat of yet another gas war between Russia and Ukraine. As a result, at the start of January 2020, the EU gas storage facilities were filled at $88 \%$, and on March 31 at $54 \%$. In terms of volumes, such reserves had been unseen for years. At the same time, in March 2020, the supplies of LNG to the EU amounted to $277 \mathrm{TWh}$. They were record high volumes (European Commission 2020).

The above-mentioned differing policies of state authorities in terms of ensuring the security of natural gas supply to domestic recipients has a significant effect on legislation regarding the use of gas storage facilities for the security of supply. Despite having common regulations under the EU law, differences between the countries in question in terms of legal requirements are present (Slobodian 2016). An example is the Hungary-specific role of Hungarian Hydrocarbon Stockpiling Association, controlled by the state and established for the purpose of strategic gas storage, or the proportion of international companies managing UGSF in Czechia. However, one cannot overestimate the significance of domestic regulations for ensuring energy security in individual countries regarding natural gas. Researchers point to the cases of a lack of determination 
of state authorities concerning the implementation of some regulations (Rosicki 2017) and the differing levels of determination of authorities of the countries in question in terms of carrying out investments in gas infrastructure (Kużelewska and Bartnicki 2017; Wojcieszak 2018).

One factor decreasing the importance of UGSF in ensuring the continuity of supply in the Visegrád Group countries is climate change. In winter, they significantly reduce disproportions in gas demand. It makes it easier to respond to increased needs of consumers at that time.

In such a situation, all the government needs to ensure technical capabilities for constant gas supply to consumers are storage facilities of a smaller capacity. However, one should remember that climate change does not exclude exceptions, e.g. in the form of a single atypical cold January and February once in 5-10 years.

However, on the other hand, climate change indirectly generates increased gas consumption in the Visegrad Group. The ecological EU policy, including the increased importance of RES, causes a significant increase of demand for gas in winter periods.

This will deepen the EU's dependency on the importation of gas, especially as, according to some calculations of western researchers, by 2030 the EU will see a $25 \%$ drop in gas production (see: Burmistrova 2020).

The security of gas supply to domestic consumers is largely affected by the use of UGSF by the Visegrad Group countries to strengthen their negotiating positions in ad hoc and strategic agreements with Russia. This pertains to both active facilities and the ones only being built.

The appropriate capacity of UGSF conditions the real liberalization of markets, as the increasing of the active capacity of USFG directly results in increasing competition on the gas market. This, in turn, improves the efficiency of gas use in the economy, increases flexibility and liquidity on the gas market. It alleviates the fluctuations of gas prices on the domestic market. It also facilitates maintaining commercial reserves of gas. Consequently, it allows a proper response to changes in demand/supply and prices of gas to be provided (Brzeziński and Wawrzynowicz 2014). It contributes to the lowering of prices of the raw material for domestic buyers and limiting the scale of energy poverty.

Due to the differentiation of relationships with the Visegrad Group countries and Russia along with climate change, the construction of UGSF is sometimes categorized as a not particularly profitable investment. This pertains to those functions of UGSF which are not subject to market valuation. Therefore, one of the threats to the role of UGSF in supplying gas to consumers is the liberalization of the gas market. Excessive focus on the business side of storage may lead to the dilution of responsibility for the security of gas supplies to consumers (Stopa and Kosowski 2018). In the case of lingering economic trends which are unfavorable for storage, it will significantly limit the expansion of the infrastructure of this part of the gas market. Low gas prices generate low seasonal price fluctuations, which discourages private investors from building storage facilities. A partial solution is of course investing in the opportunities offered by new technologies. They currently allow the cost of operation of a UGSF to be reduced by a few to over a dozen per cent (e.g. Mrzygłód 2018).

The significance of UGSF cannot be substantially decreased by gas production, because it is 3 times slower than extracting it from UGSF constructed based on depleted gas fields. At the 
same time, own deposits of gas are too small, and the costs of its production are too high. As a result, in the 2018/2019 storage year, in summer months, gas consumption was definitely higher than gas production (GIE 2020b).

However, the appropriate capacity of UGSF has a positive effect on the production of gas from domestic deposits by making its volumes independent on the seasonal changes in demand. It allows for optimizing production (Stopa and Kosowski 2018) and a rational exploitation of deposits.

From the point of view of supply security, UGSF can only partly be replaced by producing gas outside the territory of a given country, as is the case in Poland and Hungary and in the future in Slovakia (NAFTA 2018; MOL 2019; Ruszel 2017). This is so not only because there is a current lack of direct pipelines from the areas of gas extraction to Hungary and Poland.

Funds provided on the EU-level are very important in the scope of financing the construction and delivery dates for individual UGSF (Trubalska 2019). However, most funds for the construction of UGSF came directly from the budgets of individual countries of the Visegrad Group (Ciechanowska 2016).

In 2020, Agata Łoskot-Strachota pointed to the tendency "to abandon subsidizing gas investments from EU funds" (Łoskot-Strachota 2020). However, an opposite view can also be found in the literature (Dyduch and Skorek 2020). In order to increase the EU funds allocated for the construction of UGSF, the Visegrad Group needs to cooperate appropriately in the scope of the energy policy in EU structures.

In the scope of security of supplies for domestic consumers, as part of the cooperation of the Visegrad Group countries, an absolute priority has been given to the construction of industrial lines on the North-South axis and creating a regional gas market (e.g. Visegrad Group 2013; Trubalska 2016). Due to discrepancies between the countries, the full implementation of these plans by 2025 is rather unlikely (Osička et al. 2018). It significantly increased the meaning of the UGSF network in ensuring security of supplies, and fostered its expansion. A small number of main transmission gas pipelines significantly increases the consequences of a potential failure or terrorist attack.

Using the EU regulations, the government of Slovakia also fosters investments in UGSF outside the country. One example are the investments of NAFTA in gas storage facilities in Germany (NAFTA 2018).

Thanks to the appropriate use of EU regulations, in a situation of a significant disruption of gas supplied through Ukraine, it significantly increases chances for gas to be supplied to Slovakia from the West. However, in the event of a long-lasting disruption in supply, they may play only a supplementary role.

The role of UGSF in ensuring supply security is affected by insufficient funds allocated within the Visegrad Group for repairs and the replacement of old gas pipelines. In 2017, there were 34 failures on a yearly average in Poland alone (Ruszel 2017). In the face of the growing number of regional and local failures of pipelines, the appropriate distribution and use of storage facilities facilitates the recovery of supply continuity. It may be assumed that, if the government does not take decisive action, the number of failures of gas pipelines in 2025 in the area of the Visegrad Group may exceed 100 a year. 
In the long run, investments in new UGSF are inevitable also because over time the ground infrastructure requires replacement, there is a growing likelihood of an excessive amount of water accumulating in some storage facilities, leaks, lowered capacity of UGSF chambers drilled in rock salt (Mrzygłód 2018).

When analyzing the role of UGSF in ensuring supply continuity, also their role on the local level needs to be emphasized. In the winter period, they offset the local limitations of the throughput of gas systems (Stopa and Kosowski 2018). It, however, does not exhaust the issue. For instance, the construction of gas storage facilities in the North-Eastern part of Poland would facilitate the expansion of the gas infrastructure currently carried out in that area. Whereas the UGSF being designed in Pomerania could play an important role in storing supplies from Denmark and supplies obtained through the terminal in Świnoujście (GAZ-SYSTEM 2014). It would also allow supplementing deficiencies resulting from e.g. potential damage to the terminal. The local significance of UGSF in a given country surely depends on the distribution and number of storage facilities and transmission gas pipelines, since, in order to satisfy a sudden increase in demand on a local scale, gas from industrial pipelines is often used (Kutyła 2016).

The UGSF's importance for the stability of gas supplies for domestic consumers is increased in the discussed part of the EU by the small predictability of the situation on the gas market until 2025, let alone until 2040. For instance, if it is assumed that the pandemic ends in 2020, then the estimates of Mariusz Ruszel concerning the demand for natural gas in 2025 in Poland at the level of 200-211 TWh (Ruszel 2017) may be deemed minimal. On the EU scale, the low prices of gas seen already in 2020 caused a reduction in the drop in its use in individual countries (Anouk 2020). Although, as transpires from Table 1, the Polish demand for gas cannot be representative for all countries of the Visegrad Group, it is necessary to take the possibility of a significant increase in the use of natural gas in the economies of the countries in question within a time-frame until 2040 into account. In such a situation, the expansion of UGSF is a condition of a safe increase of natural gas importation.

In the discussed part of Europe, Adam Stulberg predicted the creation of hubs weakening the dependency on Russian imports (Stulberg 2015). The Polish authorities have a different definition of the hub in the area in question. The implementation of these plans also requires the expansion of UGSF.

\section{Conclusion}

Concern for UGSF is one of the conditions of expansion of transmission pipelines to the north and south, increase of LNG imports within the Visegrad Group, or the creation of a gas hub in Poland - the initiatives are aimed at, among others, securing the continuity of supplies to domestic users. 
The hypotheses put forward at the beginning of this paper were confirmed. In practice, the growing role of UGSF in ensuring supply security only in part translates into real actions and plans of the authorities. To some extent, it results from the costly nature of such investments and the profitability of maintaining storage facilities under current climate and price conditions. However, the current and planned investments indirectly indicate that in the policies of the governments of the Visegrad Group countries, UGSF are supposed to soon play a much smaller role than many researchers would expect. An intensive expansion of UGSF is very unlikely.

The cooperation between the Visegrad Group countries in the scope of energy policy in practice concerns UGSF to a small extent. Therefore, there are still significant differences in the scope of the policies of storage of natural gas between the Visegrad Group countries. However, they partly result from geological circumstances.

The scale of the state's effect on the role of storage facilities in supplying gas to users depends on the level of the state's control over the companies managing UGSF. An extreme example is the Czech storage market: it is divided into a few enterprises with different owners and is facing the expansion of Gazprom.

It has been assumed that the effect of the pandemic on the situation on the gas market will not have any consequences in a multi-annual perspective. Considering the levels of gas prices over a period of 1-2 years, this means an increase of the state's role in building storage facilities.

\section{References}

ANouk, H. 2020. Natural gas demand in Europe: The impacts of COVID-19 and other influences in 2020. Oxford: The Oxford Institute for Energy Studies.

BP Statistical Review of World Energy 2019, London: BP p.1.c.

BP Statistical Review of World Energy 2020, London: BP p.1.c.

BrZeZiŃSKi, T. and WAWrZYNOWICZ, A. 2014. Development of gas storage segment, changes in the regulatory environment, the operating principles and the role of the segment in the gas market (Rozwój segmentu magazynowania paliw gazowych, zmiany otoczenia prawnego, zasady funkcjonowania oraz znaczenie segmentu dla rynku). Rynek Energii 114(5) (in Polish).

Burmistrova, E.V. 2020. Future Natural Gas in the European Market: Gazprom's View Speech at the European Gas Conference (Buduŝeeprirodnogo gaza na evropejskom rynke: vzglâd Gazproma Vystuplenie na Evropejskoj gazovoj konferencii) (Vena, 28 ânvarâ 2020 g). [Online] http://www.gazpromexport. ru/files/EV_Burmistrova_Vena_280120722.pdf [Accessed: 2020-06-19] (in Russian).

Ciechanowska, M. 2016. Underground gas storage facilities - an element of Polish energy security (Podziemne magazyny gazu elementem bezpieczeństwa energetycznego Polski). Nafta-Gaz 72(10), DOI: 10.18668/NG.2016.10.08 (in Polish).

Dyduch, J. and Skorek, A. 2020. Go South! Southern dimension of the V4 states' energy policy strategies - An assessment of viability and prospects. Energy Policy 140.

EPH and EPIF announce completion of intra-group reorganisation and publication of Combined Financial Statements, 2016-04-12. [Online] https://www.epinfrastructure.cz/en/tiskove-zpravy/1501/\#2020 [Accessed: 2020-06-23]. 
European Commission 2020. Quarterly Report Energy on European Gas Markets Market Observatory for Energy DG Energy, Bruxelles: European Commission 13 (1).

Eurostat 2019. Energy, transport and environment statistics 2019 edition, Luxembourg: Publications Office of the European Union.

Eurostat 2020. Supply of gas. [Online] http://appsso.eurostat.ec.europa.eu/nui/submitViewTableAction.do [Accessed: 2020-09-15].

FILAR, B. 2018. Analysis of the possibility of expanding an underground gas storage facility working volume by raising the upper UGS operating pressure above the original gas reservoir pressure (Analiza możliwości rozbudowy pojemności czynnej podziemnego magazynu gazu w wyniku podnoszenia górnego ciśnienia pracy PMG powyżej pierwotnego ciśnienia złoża gazu). Nafta-Gaz 74 (4); DOI: 10.18668/ NG.2018.04.03 (in Polish).

GAZ-SYSTEM 2014. Development Plan for the Gas Transmission Operator GAZ-SYSTEM S.A. for meeting the current and future demand for gaseous fuels for 2014-2023 Extract (Plan Rozwoju Operatora Gazociagów Przesyłowych GAZ-SYSTEM S.A. w zakresie zaspokojenia obecnego i przyszłego zapotrzebowania na paliwa gazowe na lata 2014-2023 Wyciag). [Online] https://www.gaz-system.pl/fileadmin/pics_pl/Inwestycje/Plan_Rozwoju_GAZ_SYSTEM_S.A._na_lata_2014-2023.pdf [Accessed: 2020-07-14] (in Polish).

GAZPROM 2020 - Transportirowka. [Online] https://www.gazprom.ru/f/posts/34/784381/map-develop2019-ru.jpg [Accessed: 5.07.2020].

GIE 2020a. Value of the gas storage infrastructure for the electricity system Final report. [Online] https:// www.gie.eu/index.php/gie-publications/studies GIE - Capacity value of gas storage - Artelys - Final Report - final.pdf [Accessed: 2020-07-13].

GIE 2020b. System Development Map 2018/2019. [Online] https://www.gie.eu/map-order/product/entsoggie-system-development-map-2018-2019/ ENTSOG/GIE [Accessed: 2020-07-13].

GIE 2020c. Historical data. [Online] https://agsi.gie.eu/\#/historical/CZ [Accessed: 2020-07-15].

GIE 2020d. Historical data. [Online] https://agsi.gie.eu/\#/historical/SK [Accessed: 2020-07-15].

GIE 2020e. Historical data. [Online] https://agsi.gie.eu/\#/historical/PL [Accessed: 2020-07-15].

GIE 2020f. Historical data. [Online] https://agsi.gie.eu/\#/historical/HU [Accessed: 2020-07-15].

GIE Storage Map 2018. [Online] https://www.gie.eu/map-order/product/gie-storage-map-2018/ [Accessed: 2020-09-15].

Gryz et al. eds. 2018 - Gryz J., Podraza, A. and Ruszel, M. eds. Energetic safety. Concepts, challenges, interests (Bezpieczeństwo energetyczne. Koncepcje, wyzwania, interesy). Warszawa: Wydawnictwo Naukowe PWN (in Polish).

HADAM, J. 2015. The natural gas transmission system as the foundation for market security and development (System przesyłowy gazu ziemnego fundamentem rozwoju i bezpieczeństwa rynku). Przeglad Gazowniczy 45(1) (in Polish).

innogy Gas Storage 2020. Total capacity. [Online] https://www.innogy-gasstorage.cz/en/transparency/operational-information/daily-data/total-capacity [Accessed: 2020-06-23].

IEA 2019. [Online] https://www.iea.org/data-and-statistics?country=CZECH\&fuel=Natural\%20gas\&indicator=Natural\%20gas\%20production [Accessed: 2020-09-15].

KŁACZYŃSKI, R. 2017. Energy strategy of the Russian Federation in relation to the Visegrad Group countries (Strategia energetyczna Federacji Rosyjskiej wobec państw Grupy Wyszechradzkiej). Cywilizacja i Polityka 15; DOI: 10.5604/01.3001.0010.5472 (in Polish).

KŁACZYŃsKi, R. 2018. Petrol and Natural Gas Market of the Visegrád Group Countries 1993-2016: Current State and Prospects. Polish Political Science Yearbook 47 (1); DOI: 10.15804/ppsy2018 101.

KutYŁA, S. 2016. The role of gas storage facilities in ensuring energy state security (Rola magazynów gazu w zapewnieniu bezpieczeństwa energetycznego państwa). [In:] Ilnicki, M. and Nowakowski, Z. 
eds. Energy security, economy, society - selected issues (Bezpieczeństwo energetyczne, gospodarka, społeczeństwo - wybrane zagadnienia). Warszawa: Towarzystwo Naukowe Powszechne (in Polish).

KuŻelewska E. and BARTNicki A. R. 2017. The Visegrad Group - new challenges to security and cooperation prospects (Grupa Wyszehradzka - nowe wyzwania bezpieczeństwa i perspektywy wspótpracy). Rocznik Integracji Europejskiej 11 (in Polish).

Losкот-Strachota, A. 2020. Turbulent waters - the European gas market during a pandemic (Wzburzone wody - europejski rynek gazu w czasie pandemii). [Online] https://www.osw.waw.pl/pl/publikacje/ komentarze-osw/2020-04-15/wzburzone-wody-europejski-rynek-gazu-w-czasie-pandemii\#_ftnref1 [Accessed: 2020-06-28] (in Polish).

MejsTřík, M. 2011. Ensuring energy security in the field of natural gas supply (Zajištěni energetické bezpečnosti $v$ oblasti dodávek zemniho plynu). [Online] http://ies.fsv.cuni.cz/default/file/download/ id/16296 [Accessed: 2020-06-23] (in Czech).

MichaliK, D. 2019. Energy cooperation in the Visegrad Group: chances and threats in 2019 (Wspótpraca energetyczna w Grupie Wyszehradzkiej - szanse i zagrożenia 2019). [In:] Ruszel M. and Podmiotko S. eds. Energy security of Poland and Europe: Conditions - challenges - innovations (Bezpieczeństwo energetyczne Polski i Europy. Uwarunkowania - wyzwania - innowacje). Rzeszów: Instytut Polityki Energetycznej im. I. Łukasiewicza (in Polish).

Mirovidov, K.N. 2017. Assessment of competitive options for the reproduction of oil and gas reserves (Otsenka konkurentnykh variantov vosproizvodstva zapasov hefti i gaza). [In:] Zhukov V. ed., World oil and natural gas markets: heightened competition (Mirovye rynki nefti i prirodnogo gaza: uzhestotsenie konkurentsii). Moskva: IMEMO RAN (in Russian).

MND 2019. MND Gas Storage a.s. Annual Report 2019 (Výroční zpráva 2019) [Online] https://www.gasstorage.cz/wp-content/uploads/2020/05/V\%C3\%BDro\%C4\%8Dn\%C3\%AD-zpr\%C3\%A1va-MNDGas-Storage_2019.pdf 2020-07-05 [Accessed: 2020-07-05] (in Czech).

MOL 2019. MOL Group Integrated Annual Report 2019. [Online] https://molgroup.info/storage/documents/publications/annual_reports/2019 [Accessed: 2020-07-13].

MrZYGŁóD, R. 2018. Modern management of underground gas storage facilities (Nowoczesne zarzadzanie podziemnym magazynem gazu). Przeglad Gazowniczy 58(2) (in Polish).

NAFTA 2018. Annual Report NAFTA. [Online] http://www.nafta.sk/sites/default/files/vyrocna_sprava_2018_web_sken_final.pdf [Accessed: 2020-06-23].

NAFTA 2020. Powers and capacities of the tank (Výkony a kapacity zasobnika). [Online] https://isodzz. nafta.sk/yCapacity/\#/?nav=ss.od.sc [Accessed: 2020-06-23] (in Slovak).

Naftogaz 2020. Gas Balances in European Underground Storages [Online] https://naftogaz-europe.com/ article/en/GasBalances [Accessed: 2020-09-15].

Olkuski et al. 2017 - Olkuski, T., Sikora, A., Sikora, M.P. and Szurlej, A. 2017. The forecasted production, consumption, and net exports of energy resources in Poland (Prognozy wydobycia, konsumpcji $i$ salda wymiany surowców energetycznych $w$ Polsce). Polityka Energetyczna - Energy Policy Journal 20(2) (in Polish).

Olkuski et al. 2015 - Olkuski, T., Szurlej, A. and JANusz, P. 2015. Energy policy implementation in natural gas (Realizacja polityki energetycznej w obszarze gazu ziemnego). Polityka EnergetycznaEnergy Policy Journal 18(2) (in Polish).

OsičKa et al. 2018 - OsičKA, J., LeHOTSKÝ, L., ZAPLETAlová, V., ČERnOCH, F. and DANČÁK, B. 2018. Natural gas market integration in the Visegrad 4 region: An example to follow or to avoid? Energy Policy 112.

PEP 2040. Polish Energy Policy until 2040 (Polityka energetyczna Polski do 2040 roku). [Online] https:// www.gov.pl/web/aktywa-panstwowe/zaktualizowany-projekt-polityki-energetycznej-polski-do-2040-r [Accessed: 2020-06-20] (in Polish).

PEP 2040 summary. Polish Energy Policy until 2040 - summary (Polityka energetyczna Polski do 2040 roku-streszczenie). 2020-09-08 [Online] https://www.gov.pl/web/klimat/minister-kurtyka-polityka-e- 
nergetyczna-polski-do-2040-r-udziela-odpowiedzi-na-najwazniejsze-wyzwania-stojace-przed-polska -energetyka-w-najblizszych-dziesiecioleciach [Accessed: 2020-09-15] (in Polish).

PGNiG 2020. Underground gas storage facilities (Podziemne magazyny gazu). [Online] http://pgnig.pl/ podziemne-magazyny-gazu [Accessed: 2020-07-15] (in Polish).

Report on the activities of the President of the Energy Regulatory Office in 2019 (Sprawozdanie z działalności Prezesa URE w 2019 r.), Warszawa: URE (in Polish).

Rosicki, R. 2017. Poland's energy policy: main problems and forecasts. Środkowoeuropejskie Studia Polityczne 2; DOI 10.14746/ssp.2017.2.4.

Ruszel, M. 2017. Evaluation of the Security of Natural Gas Supplies to Poland: the Present State and the 2025 Perspective (Ocena bezpieczeństwa dostaw gazu ziemnego do Polski-stan obecny i perspektywa do 2025 r.). Polityka Energetyczna - Energy Policy Journal 20(1) (in Polish).

Ruszel, M. and Szurlej, A. 2016. Natural gas sector in the V4 countries (Sektor gazu ziemnego w państwach V4). Przegląd Gazowniczy 49(1) (in Polish).

Schultz et al. 2020 - Schultz, R.A., HubBard, D.W., Evans, D.J. and Savage, S.L. 2020. Characterization of Historical Methane Occurrence Frequencies from U.S. Underground Natural Gas Storage Facilities with Implications for Risk Management, Operations, and Regulatory Policy. Risk Analysis 40(3).

SKRZYŃSKI, T. 2019. In the face of the rising importance of natural gas to the Polish economy. Zarzadzanie Publiczne - Public Governance 47 (1).

Slobodian, N. 2016, Report. Gas market and energy security in the Visegrad Group countries: models, challenges and outlooks (Raport. Rynek gazu i bezpieczeństwo energetyczne w państwach Grupy Wyszehradzkiej: modele, wyzwania i perspektywy). Warszawa: Narodowe Centrum Studiów Strategicznych (in Polish).

SLOVSTAT 2020. [Online] http://datacube.statistics.sk/\#!/view/en/VBD_SLOVSTAT/en2010rs/v_en2010rs_00_00_00_en [Accessed: 2020-07-15].

SöNNICHSEN, N. 2020. Technical working gas volume in underground storage facilities in Europe by country as of 2018 (in terawatt hours). [Online] https://www.statista.com/statistics/688149/undergroundgas-storage-volume-by-country-europe/ [Accessed: 2020-07-15].

Stopa, J. and Kosowski, P. 2018. UGSF in Poland against the background of the European gas market (PMG w Polsce na tle europejskiego rynku gazu). Przeglad Gazowniczy 57 (1) (in Polish).

Stopa et al. 2019 - StOPA, J., KuK, D. and JANIGA, B. 2019. Innovative gas supply: artificial intelligence methods in the exploitation of underground storage facilities and deposits of natural gas (Innowacyjne gazownictwo - metody sztucznej inteligencji w eksploatacji złóż i podziemnych magazynów gazu ziemnego). Przeglad Gazowniczy 61(1) (in Polish).

Stulberg, A. N. 2015. Out of Gas?: Russia, Ukraine, Europe, and the Changing Geopolitics of Natural Gas. Problems of Post-Communism 62 (2); DOI: 10.1080/10758216.2015.1010914.

TomaszewsKi, K. 2018. Energy solidarity in the European Union in the context of the particular interests of the Member States. Polityka Energetyczna - Energy Policy Journal 21(2).

TrubalsKa, J. 2016. Trans-European Energy Infrastructure Projects. The Case of the North-South Gas Corridor. Humanities and Social Sciences 21, 23 (1).

TrubalsKa, J. 2017. Towards energy union: the new concept of energy security in the European Union (W kierunku unii energetycznej. Nowa koncepcja bezpieczeństwa energetycznego w Unii Europejskiej), Zeszyty Naukowe Instytutu Gospodarki Surowcami Mineralnymi i Energia PAN 97 (in Polish).

TRUbalsKa, J. 2019. The prospects for energy cooperation in the Visegrad Group. Annales Universitatis Mariae Curie-Sklodowska M, 4; DOI: 10.17951/m.2019.4.

Visegrad Group 2013. Road Map towards the regional gas market among Visegrad 4 countries. [Online] http://www.visegradgroup.eu/documents/official-statements [Accessed: 2019-08-09].

Wang T. World natural gas consumption by country 2018. [Online] https://www.statista.com/statistics/265407/world-natural-gas-consumption-by-country/; [Accessed: 2020-04-26]. 
Wif̨CKOwSKI, R. 2015. The role of gas storage facilities on emerging and mature markets of natural gas (Rola magazynów gazu na wschodzacych oraz dojrzatych rynkach gazu ziemnego). Przegląd Gazowniczy 54(2) (in Polish).

WojCIESZAK, Ł. 2018. Specifics of the Hungarian gas security (Specyfika bezpieczeństwa gazowego Węgier). [In:] Wojcieszak Ł. ed., Central and Eastern Europe and specific problems of energy security (Europa Środkowa $i$ Wschodnia wobec wybranych problemów bezpieczeństwa energetycznego). Poznań: Fundacja na rzecz Czystej Energii (in Polish).

Tomasz SKRZYŃSKI

\section{Rola podziemnych magazynów gazu w zapewnianiu ciągłości dostaw gazu ziemnego do odbiorców krajowych na przykładzie państw Grupy Wyszehradzkiej}

\section{Streszczenie}

W omawianej części Europy podziemne magazyny gazu pełnią ważną rolę w utrzymywaniu równowagi pomiędzy stale importowanym surowcem a zmiennym zapotrzebowaniem na gaz. Umożliwiają także bardziej wydajną pracę przedsiębiorcom wydobywającym ten surowiec w omawianej części Europy oraz operatorom linii przesyłowych.

W artykule omówione zostały następujące zagadnienia: rodzaje, pojemność, rozmieszczenie i zmienność poziomu zapełnienia podziemnych magazynów gazu na terenie Polski, Czech, Węgier i Słowacji; podobieństwa i różnice polityki odnośnie do magazynowania gazu ziemnego między poszczególnymi państwami Grupy Wyszehradzkiej; wpływ tych różnic na sytuację na rynku gazowym; wpływ, jaki dla bezpieczeństwa energetycznego poszczególnych państw - członków Grupy Wyszehradzkiej będzie miała planowana dalsza rozbudowa systemu magazynów gazu ziemnego.

Troska o PMG jest jednym z warunków rozbudowy gazociągów przesyłowych w kierunku północnym i południowym, wzrostu możliwości importu NLG na teren Visegrad Group czy stworzenia w Polsce hubu gazowego - inicjatyw mających na celu m.in. zabezpieczenie ciągłości dostaw do odbiorców krajowych.

Obecne i planowane inwestycje pośrednio wskazują jednak, że w polityce władz państw Grupy Wyszehradzkiej, PMG mają w najbliższej przyszłości pełnić wyraźnie mniejszą rolę niż przewiduje wielu badaczy. Mało prawdopodobny jest wariant intensywnej rozbudowy PMG.

Skala wpływu państwa na rolę magazynów w dostarczaniu surowca do odbiorców jest uzależniona od stopnia jego kontroli nad firmami zarządzającymi PMG.

SŁowa KLUCzowe: polityka energetyczna, podziemne magazyny gazu, rynek gazu ziemnego, infrastruktura gazowa 
